\title{
Pruning Effects on the Health of Indian Sandalwood (Santalum album Linn) in Agroforestry Conditions of South India
}

\author{
Ramachandran Sundararaj", Soma Mondal, Mustipally Kanthareddy \\ Forest Protection Division, Institute of Wood Science and Technology, Malleshwaram, Bangalore, India \\ Email address: \\ rsundariwst@gmail.com (R. Sundararaj), somamanda129@gmail.com (S. Mondal), kanthu.biochem@gmail.com (M. Kanthareddy) \\ To cite this article: \\ Ramachandran Sundararaj, Soma Mondal, Mustipally Kanthareddy. Pruning Effects on the Health of Indian Sandalwood (Santalum album \\ Linn) in Agroforestry Conditions of South India. American Journal of Plant Biology. Vol. 4, No. 1, 2019, pp. 1-6. \\ doi: 10.11648/j.ajpb.20190401.11
}

Received: March 18, 2019; Accepted: April 29, 2019; Published: June 12, 2019

\begin{abstract}
Surveys in south India revealed that Santalum album Linn. is commonly grown with forest trees and horticultural and agricultural crops. As a silvicultural practices in cultivation of S. album though pruning is not recommended many farmers follow the practice of regular pruning there by adversely affecting the health of trees. Severely pruned trees were found losing their erectness and bending indicating that pruning causes change, disorder and affect many physiological functions resulting in deterioration of overall tree health. The wounds caused by pruning sever tissue connections and enhances the infection of decay fungi. It attracts the infestation of insect pests particularly the stem and wood borers. The incidence of bark caterpillar Indarbela quardinotata Walker, red stems borer Zeuzera coffeae Nietn. and heart wood borer Aristobia octofasciculata Aurivillius was found significantly higher in pruned plantations compared un-pruned plantations. The heartwood loss ranging from 22.6 to $34.5 \%$ was observed during extraction and this loss might be attributed due to the adverse effect of pruning and other mechanical injuries inducing infection of decay fungi and infestation of stem borers in young plantations of S. album. Hence, to avoid not only the pruning but also any silvicultural practices that cause injury to sandalwood are recommended for its healthy growth and thereby to obtain desirable returns.
\end{abstract}

Keywords: Santalum Album, Stem Borer, Pruning, Silviculture, Agroforestry

\section{Introduction}

Indian sandalwood (Santalum album Linn) which is acknowledged as "Royal Tree" in Indian subcontinent is one of the most economically important tree species occupying a pre-eminent position in Indian forestry. The tree has been synonymous with ancient Indian culture and is having long history through and its importance and medicinal value has been mentioned in many quotes of age-old writings. For more than 5000 years, India has been the traditional leader of sandalwood oil production for perfumery and pharmaceuticals [1]. The economic importance of sandalwood is well documented and is the second most expensive wood in the world [2]. During the past one hundred years, the prices of sandalwood have seen many variations. The annual global sandalwood production is estimated to be approximately 5610 tonnes which has declined markedly over the past 20-30 years. The production of sandalwood in India decreased annually at the rate of 20 percent since 1995 [3]. Due to increased demand in internal and external markets and also the decrease in supply, sandalwood price has skyrocketed. As per Karnataka Government outlet 2012, cost of $5 \mathrm{~g}$ of oil sold is Rs 1500 , which works out to be Rs $300,000 / \mathrm{kg}$ [2]. The decline in sandalwood production is mainly due to the depletion of sandalwood trees in forest. The depletion is attributed to factors like illicit felling, disease and smuggling, which are very rampant and is the major problem in the entire sandalwood tree growing states [4]. Due to the drastic reduction in the population of sandalwood in natural sandalwood growing states of south India viz, Karnataka and Tamil Nadu and realizing that the existing rules are primarily responsible for its reduction the states have amended the Sandalwood rule which clearly states that "every occupant or 
the holder of the land shall be legally entitled to the sandalwood tree in his land". The purpose of the amendment is to encourage farmers and corporate bodies to take sandalwood plantations to meet the growing demand [5]. The most important characteristic of sandalwood tree is its hemiparasitic nature which makes it good species for agroforestry setup and it can parasitize over 300 species of plants [6]. The above facts encouraging community and private entrepreneurs to cultivate S. album in agro-forestry, farm forestry and varied agri-silvi-horticultural and mixed plantation systems as per their choice and many small to large scale plantations are coming up. In this context, many complaints have been received from sandalwood growers reporting death of sandalwood trees. Hence, surveys were conducted to assess the farmer's way of growing sandalwood in south India with their health status and the reason for the death of trees were analyzed and the findings are presented in this communication.

\section{Materials and Methods}

Surveys were conducted in states of south India viz, Andhra Pradesh, Karnataka, Tamil Nadu and Telangana covering different sandalwood plantations grown by farmers. In each field, the details of other agricultural/horticultural and forestry tree species grown along with sandalwood were recorded. Further, in farmers' field from 2015 to 2016 observations were taken on the general health and incidence of different stem borers of S. album viz. bark caterpillar, Indarbela quadrinotata Walker, red stemborer Zeuzera coffeae Nietn. and heartwood borer Aristobiaoctofasciculata Aurivillius which followed pruning and no pruning. For this purpose ten plantations each of S. albumwhich followed pruning and no pruning were selected for the study. The overall health of the plants which experienced pruning and no-pruning were assessed. The percentage incidence of different bores was also assessed in these plantations. The data thus collected were pooled and t test was performed to compute the difference in the incidence of borers in these plantations. In addition, decay caused by the entry of fungus in the cut ends was assessed and their impact on the health status was assessed.

\section{Results and Discussion}

Surveys revealed that $\mathrm{S}$. album is commonly grown with forest trees and horticultural and agricultural crops (Table 1) as per the local soil conditions and the requirement of the farmers.

Table 1. Farmer's choice of growing sandalwood with other plant species.

\begin{tabular}{|c|c|c|}
\hline SI NO. & Plant Species & Economical Importance \\
\hline 1 & Acacia auriculiformisA. Cunn & Forestry/Timber \\
\hline 2 & A. nilotica L. & Forestry/Timber \\
\hline 3 & Anacardium occidentale L. & Commercial/Traditional medicine \\
\hline 4 & Areca catechu L. & Commercial/Ornamental \\
\hline 5 & Azadirachta indica A. Juss. & Commercial/Horticulture \\
\hline 6 & Cajanus cajan (L) Millsp. & Agriculture/Food Industry \\
\hline 7 & Capsicum annuum $\mathrm{L}$. & Horticulture/Traditional medicine \\
\hline 8 & Carica papaya L. & Horticulture/Culinary \\
\hline 9 & Casuarina equisetifolia L. & Commercial/removal of textile dye \\
\hline 10 & C. junghuhniana Miq. & Commercial/removal of textile dye \\
\hline 11 & Cocos nucifera $\mathrm{L}$. & Horticulture/Traditional medicine/Food industry \\
\hline 12 & Coffea arabica L. & Commercial/Traditional \\
\hline 13 & C. robusta L. Linden & Commercial/Traditional \\
\hline 14 & Cucumis sativus L. & Food Industry/Horticulture \\
\hline 15 & Curcuma longaL. & Medicinal/Culinary \\
\hline 16 & Cymbopogon citrates (DC. ex Nees) & Medicinal \\
\hline 17 & Dalbergia latifoliaRoxb. & Agriculture/Commercial \\
\hline 18 & Eleusine coracana Gaertn. & Soil stabilizer/Industrial \\
\hline 19 & Eucalyptus spp. & Commercial/Timber \\
\hline 20 & Gmelina arborea Roxb. & Commercial/Timber \\
\hline 21 & Grevillea robusta A. Cunn. & Agriculture/Horticulture \\
\hline 22 & Jasminum sambac (L) Aiton & Horticulture/Ornamental/Traditional medicine \\
\hline 23 & Macrotyloma uniflorum (Lam) Verdc. & Traditional medicine/Food industries \\
\hline 24 & Mangifera indica L. & Horticulture/Traditional medicine/Wood industry \\
\hline 25 & Manilkara zapota (L) P. Royen & Horticulture \\
\hline 26 & Melia dubia Cav. & Agro Forestry/commercial \\
\hline 27 & Moringa oleifera Lam & Horticulture/Culinary \\
\hline 28 & Musa spp. L. & Horticulture/Fertilizer industries/Culinary \\
\hline 29 & Phyllanthus emblica L. & Horticulture/Traditional medicine \\
\hline 30 & Pongamia pinnata (L) Pierre & Landscaping purposes/commercial/Ornamental \\
\hline 31 & Psidium guajava $\mathrm{L}$. & Wood industry/Horticulture/Food industry \\
\hline 32 & Pterocarpus santalinus L. f. & Commercial/Forestry \\
\hline 33 & Punica granatum $\mathrm{L}$. & Horticulture/Culinary \\
\hline 34 & Sesbania grandiflora (L) Poiret & Culinary/Medicinal \\
\hline 35 & Sorghum bicolor (L) Moench & Agriculture/Industrial \\
\hline
\end{tabular}




\begin{tabular}{lll}
\hline SI NO. & Plant Species & Economical Importance \\
\hline 36 & Syzygium cumini L. & Horticulture/Traditional medicine/Food industry \\
37 & Tectona grandisL.f. & Commercial/Forestry \\
38 & Vanilla planifolia Jacks. & Commercial/Domestic \\
39 & Vigna unguiculata (L) Walp. & Culinary \\
40 & Zingiber officinale Roscoe & Medicinal/Culinary \\
\hline
\end{tabular}

The inter-cultivation of sandalwood with other plants are commonly preferred than the pure plantations. It confirms the fact that the cultivation of $\mathrm{S}$. album absolutely requires the host plant [7]. In the cultivation of S. album though pruning is not recommended as a silvicultural practice, many farmers follow the practice of regular pruning which was found affecting the general health of the trees. Severely pruned trees were found losing their erectness and bending indicating that pruning causes change, disorder and affect many physiological functions resulting in deterioration of overall tree health (Figure 1). This compelled the farmers to give support to the plants by bamboo or other wooden poles (Figure 2) for erectness which led to attraction of termites and enhance their infestation (Figure 3). The wounds caused by pruning sever tissue connections and enhances the infection of decay fungi (Figure 4, 5). In many cases, extreme pruning resulted in death of plants (Figure 6). The death starts from top, whole plant dies, and in rare cases, recovery by new sprouting from the base was observed (Figure 7). The findings corroborates the report of $[8,9]$ and reported many species of rotting fungi from the old, rotted, vascular tissue of pruning wounds and in deep cracks in cordons, trunks, and spurs of grapevine [10]. Several rot fungi were isolated from S. album in Western Australia and reported that the fungi were entering the branches and main stem via wounds made during pruning or when branches are damaged [11]. Heartwood rot fungal diseases entering via the pruning wound has the potential to significantly reduce the sandalwood oil production [12]. Further the wounds caused by the pruning attracts the infestation of insect pests particularly the stem and wood borers. The incidence of I. quardinotata, Z. coffeae. and A. octofasciculata was found significantly higher in pruned plantations compared unpruned plantations (Table 2).

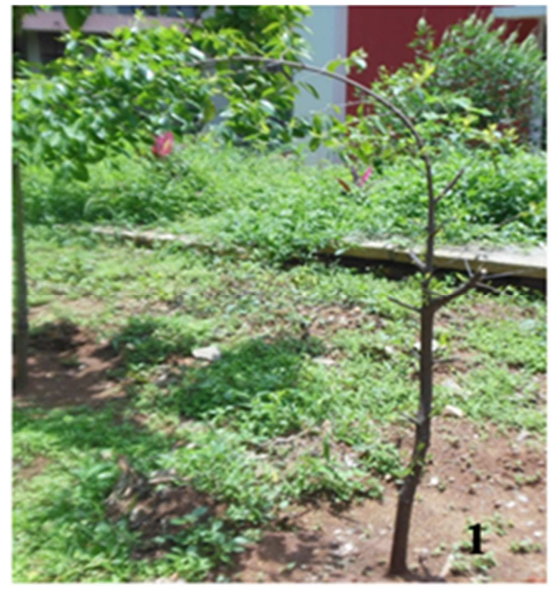

Figure 1. Bending of S. album due to severe pruning.

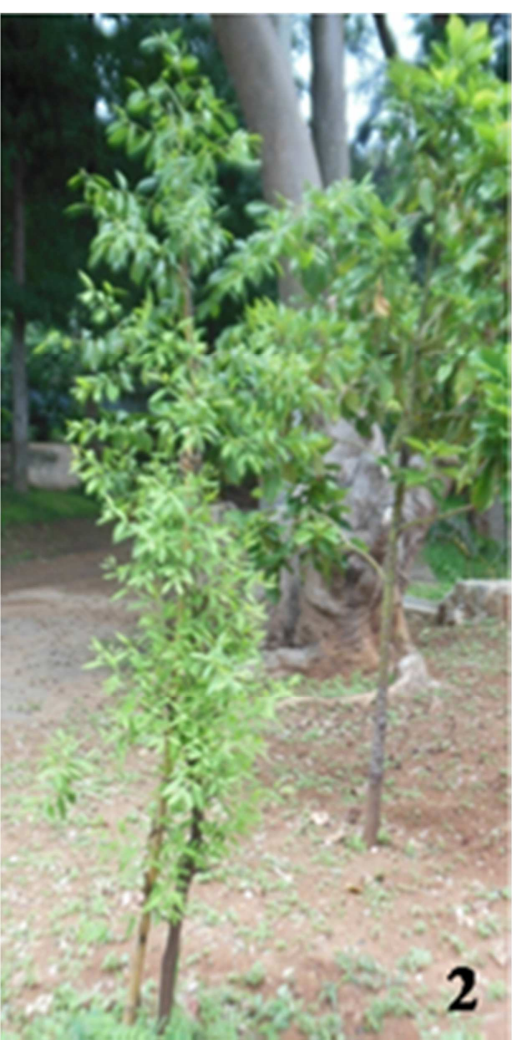

Figure 2. Severely pruned S. album with support.

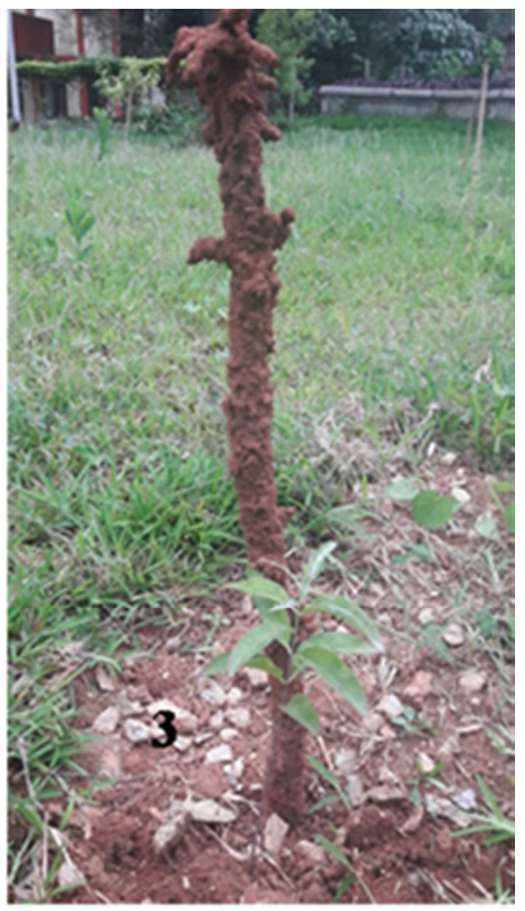

Figure 3. Termite damage in the wooden support. 


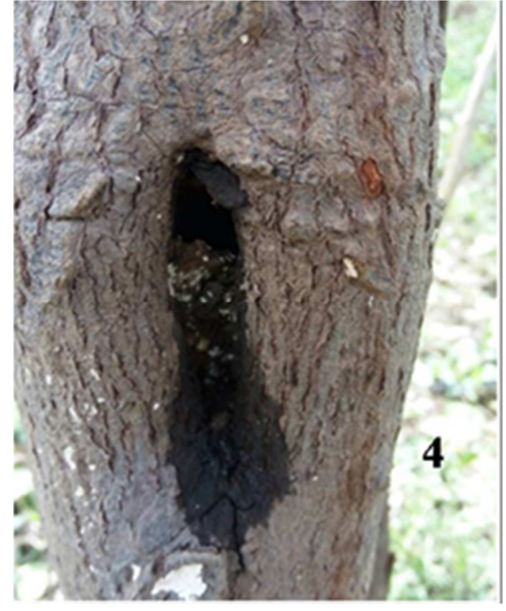

Figure 4. Entry of decay and bio-deterioration due to pruning.

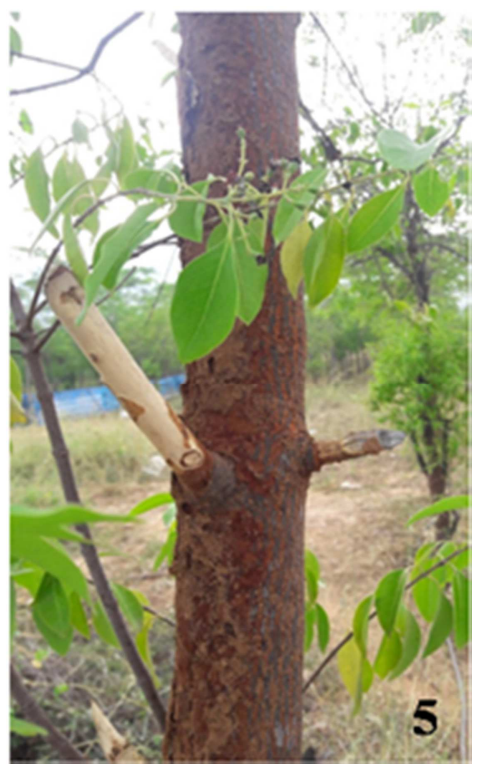

Figure 5. Termite damage in pruned S. album.

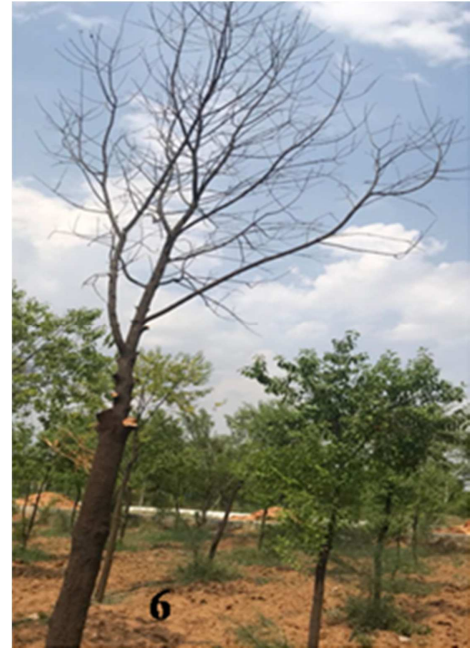

Figure 6. Death of S. album due to severe pruning.

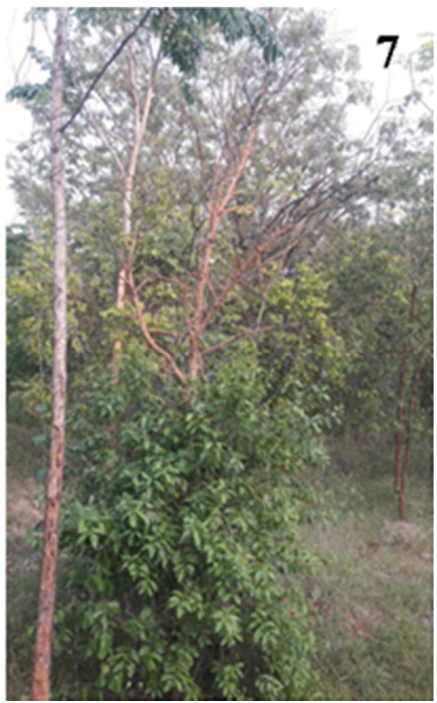

Figure 7. New sprouts from the base of severely pruned S. album.

Table 2. Impact of pruning on the incidence of stem borers in sandalwood.

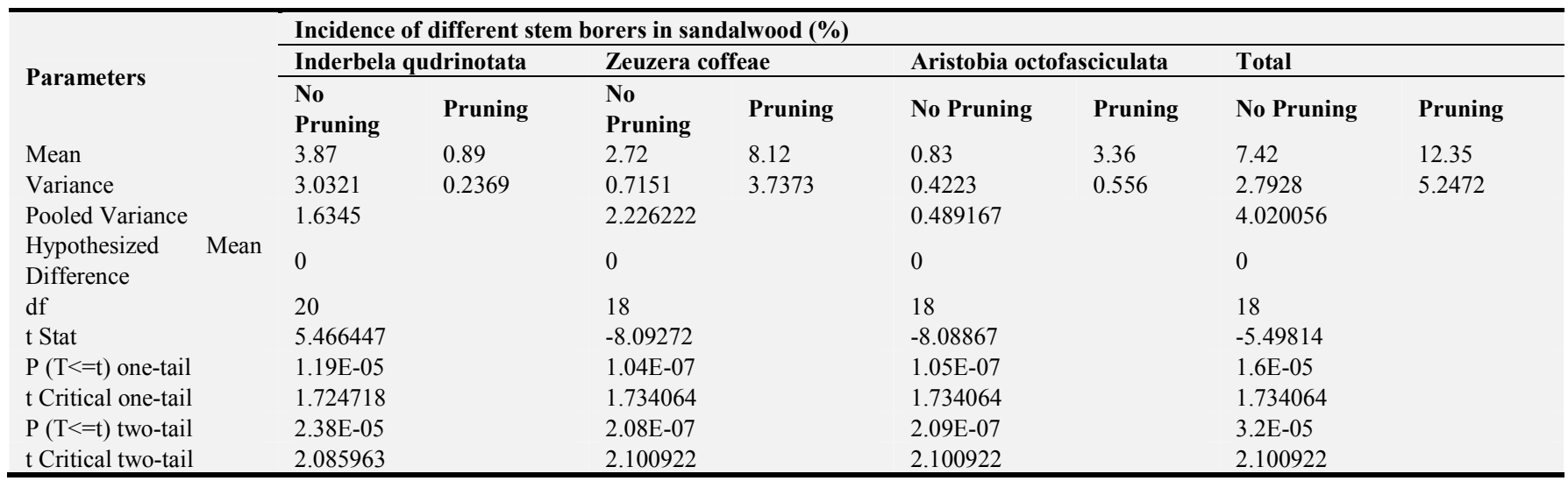

Many insects are known to be attracted to wound for laying eggs [13], wounds attract more damaging pests [14], wounds may provide oviposition sites [15], and insect takes advantage of wounds [16]. Some host kairomones released due to wound may have long range attraction potential [17]. The heartwood loss ranging from 22.6 to $34.5 \%$ (Figure 8 ) was observed during extraction of sandalwood and this loss might be attributed due to the adverse effect of pruning and 
other mechanical injuries inducing infection of decay fungi and infestation of stem borers in young plantations of $\mathrm{S}$. album. These bio-deteriorating agents would have been active for many years during the growth of sandalwood resulting in extensive loss of valuable sandalwood. It confirms the fact that such infection is carried throughout the life of sandalwood resulting in more than one-third loss of heartwood [18]. Also though selection cutting has many advantages, its potential for damage to residual trees is a major challenge of forest management [19]. Hence, silvicultural practices that cause injury to sandalwood to be avoided and no pruning should be followed to curtail the attack of bio-deteriorating agents, thereby healthy growth of sandalwood and the desirable returns are assured.

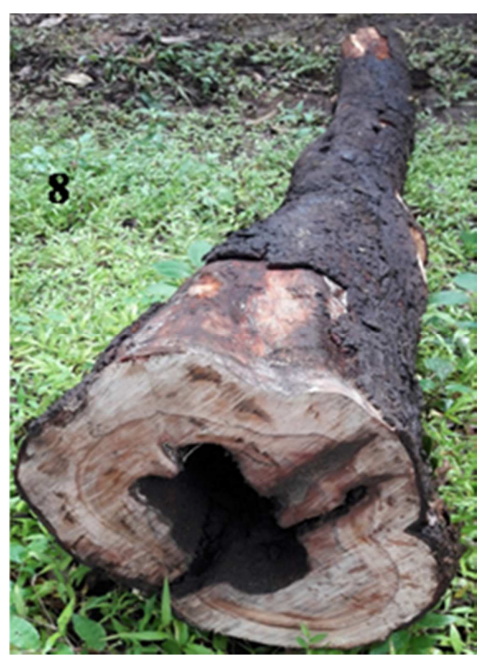

Figure 8. Heartwood loss in extracted S. album.

\section{Conclusion and Recommendation}

Any form of mechanical injury and the practice of pruning were found adversely affecting the overall health of S. album, and in severe cases causing death of trees. It also enhances the incidence and establishment of bio-deteriorating agents. Hence, it is recommended to avoid not only the pruning but also any silvicultural practices that cause injury to sandalwood for its healthy growth and thereby to obtain desirable returns.

\section{Acknowledgements}

The authors are thankful to the Director, and Group Co-ordinator (R) Institute of Wood Science and Technology, Bengaluru for the facilities provided.

\section{References}

[1] R. Hansda (2009). The outlook for non wood forest products in Asia and Pacific. Working Paper No. APFSOS II/WP/2009/18. Food and Agriculture Organisations Regional Office, Bangkok, p. 89.
[2] A. N. Arun Kumar, G. Joshi and H. Y. Mohan Ram (2012). Sandalwood: history, uses, present status and the future. Current Science 103 (2): 1408-1416.

[3] H. S. Ananthapadmanabha (2000). Sandalwood and its marketing trend. My forest 36: 147-151.

[4] N. M. Rao, S. Padmini, K. N. Ganeshaiah and R. Umashankar (1999). Sandal genetic resources of South India: threats and conservation approaches. p. 63. In: National symposium on role of plant tissue culture in biodiversity conservation and economic development. Kosi-Katarmal, Alomora.

[5] V. S. V. Gowda, K. B. Patil and B. H. Anilkumar (2008). Natural sandalwood industry- present scenario and future prospects. In: Proceedings of the National seminar on "Conservation, improvement, cultivation and management of sandal (Santalum album L)" S. Gairola, T. S. Rathore, G. Joshi, A. N. Arun Kumar and Pankaj Aggarwal, Eds, Brilliant Printers, Bangalore, pp. 196-203.

[6] R. Sundararaj, R. R. Shanbhag and B. Lingappa (2018). Habitat diversification in the cultivation of Indian sandalwood (Santalum album Linn): An ideal option to conserve biodiversity and manage insect pests. Journal of Biological Control 32 (3): 160-164.

[7] T. Lion (2017). "Sandalwood cultivation". International Journal of Development Research 7 (08), 14826-14830.

[8] A. Eskalen, S. Rooney-Lathamand W. D. Gubler (2005). Occurrence of Togninia fraxinopennsylvanica on escadiseased grapevines (Vitis vinifera) and declining ash trees (Fraxinus latifolia) in California. Plant Disease 89: 528.

[9] S. Rooney-Latham, A. Eskalen and W. D. Gubler (2005). Teleomorph formation of Phaeoacremonium aleophilum, cause of esca and grapevine decline in California. Plant Disease 89: 177-184.

[10] M. A. Baloyi, F. Halleen, L. Mostert and A, Eskalen (2013). First report of Togninia minima perithecia on esca- and Petridiseased grapevines in South Africa. Plant Disease 97: 124.

[11] D. Gramaje, M. León, A. Pérez-Sierra, T. Burgess and J. Armengol (2014) New Phaeoacremonium species isolated from sandalwood trees in Western Australia. IMA Fungus, 5 (1): $67-77$.

[12] T. I. Burgess and E. Steel. (2018). To prune or not to prune; pruning induced decay in tropical sandalwood. Forest Ecology and Management, 430: 204-218.

[13] C. Castrillon and J. G. Herrera (1980). Los picudos, negros y rayados del plátano y banano. ICA-Informa, Separata, 14.

[14] J. M. S. Ferreira, D. R. N. Warwick and L. A. Siquei, eds (1994). Cultura do coqueiro no Brasil. EMBRAPA-SPI, Aracajú, Brazil.

[15] D. Mariau and B. Mallet (1999). Cultural techniques. In: D. Mariau (ed) Integrated Pest Management of Tropical Perennial Crops, translation of Lutte Intégrée contre les Ravageurs des Cultures Pérennes Tropicales, published by Centre de Coopération International en Recherché Agronomique pour le Development, 1997. Science Publishers and CIRAD, Enfield, New Hampshire, USA, p. $112-122$ 
[16] F. W. Howard (2001). Principles of Insect Pest Control on Palms in Insects on Palms, F. W. Howard, D. Moore, R. M. Giblin-Davis and R. G. Abad (eds). CABI Publishing, CAB International, Wallingford, Oxon OX10 8DE, UK, p. 315-321.

[17] N. E. Gunawardena, F. Kern, E. Janssen, C. Meegoda, D. Schafer, O. Vostrowsky and H. J. Bestmann (1998). Host attractants for red weevil, Rhynchophorus ferrugineus: identification, electrophysiological activity, and laboratory bioassay. Journal of Chemical Ecology 24: 425-437.
[18] R. Sundararaj, J. J. Wilson and D. Vimala (2019). Stem borers of Indian sandalwood (Santalum album Linn) in Karnataka, India. Journal of Indian Academy of Wood Science https://doi.org/10.1007/s13196-019-00232-1.

[19] F. Tavankara, A. E. Bonyadb and B. Majnounianc (2015). Affective factors on residual tree damage during selection cutting and cable-skidder logging in the Caspian forests, Northern Iran. Ecological Engineering 83: 505-512. 